\title{
Plasma and testicular testosterone levels, volume density and number of Leydig cells and spermatogenic efficiency of rabbits
}

\author{
A.C.S. Castro ${ }^{1}$ \\ W.E. Berndtson ${ }^{2}$ \\ and F.M. Cardoso 3
}

\author{
1Departamento de Morfologia, Instituto de Ciências Biológicas, \\ Universidade Federal de M inas Gerais, Belo Horizonte, MG, Brasil \\ ${ }^{2}$ Department of Animal and Nutritional Sciences, U niversity of $\mathrm{N}$ ew $\mathrm{H}$ ampshire, \\ Durham, NH, USA \\ ${ }^{3}$ Departamento de Medicina Veterinária, Pontifícia Universidade Católica de \\ M inas Gerais, Betim, MG, Brasil
}

\section{Correspondence \\ A.C.S. Castro \\ Departamento de Morfologia \\ ICB, UFM G \\ Av. Antonio Carlos, 6627 \\ 31270-901 Belo Horizonte, MG \\ Brasil \\ E-mail: acastro@mono.icb.ufmg.br}

Research supported by FAPEMIG, CAPES and Experimental Agricultural Station of Durham, $\mathrm{NH}$, USA.

Received October 9, 2001 Accepted February 25, 2002

\begin{abstract}
Plasma and tissue testosterone concentrations were determined by radioimmunoassay in 12 eight-month-old sexually mature New Zealand White rabbits and evaluated for possible associations with spermatogenic efficiency as well as with volume density and number of Leydig cells. Testicular tissue was processed histologically and histometry was performed in order to quantify germ cells, Sertoli cells and Leydig cells. Spermatogenic efficiency, reported as the ratios among germ cells (spermatogonia, primary spermatocytes and round spermatids) and by the ratio of germ cells to Sertoli cells, was not associated with testosterone levels. However, Leydig cell parameters such as number of Leydig cells per gram of testis, total number of Leydig cells per testis and percent cell volume of Leydig cell nuclei were correlated significantly with testosterone levels. The statistically significant correlation $(\mathrm{r}=0.82, \mathrm{P}<0.05)$ observed between testosterone levels and the number of Leydig cells per gram of testis suggests that, in the rabbit, the latter parameter can serve as a criterion for monitoring testosterone levels in this species under normal conditions.
\end{abstract}

\section{Introduction}

Spermatogenesis depends on the action of testosterone (1). This hormone can either diffuse to the seminiferous tubule or bind to a carrier such as albumin, which takes testosterone through the lymph spaces into the seminiferous tubule. High local levels of testosterone are found surrounding the seminiferous tubules due to the close proximity of the latter to the Leydig cells. In rats, the intratesticular levels of testosterone necessary to maintain spermatogenesis are estimated to be about $25-45 \%$ of the normal levels (1). Testosterone is needed to initiate spermatogenesis at puberty and for the maintenance of this process in the adult. It is also required for the completion of meiosis and for the differentiation of the spermatids (2). Although several other androgens (such as dihydrotestosterone, dehydroepiandrosterone and androstenedione) are produced in small 
amounts by the testis, testosterone seems to be the major androgen present in the blood of several species, including the rabbit $(3,4)$.

The rabbit has served as a good and practical model in studies of basic spermatogenesis as well as for investigating effects of potential toxins or other agents on that process. In addition, it also permits a prompt analysis of both daily sperm production and daily sperm output (5).

In spite of the well-established functions of testosterone in the adult rabbit, at present there is no information on quantitative data on blood and testicular testosterone concentrations and their relationship with the population of germ cells (i.e., spermatogonia, primary spermatocytes and spermatids). Furthermore, information concerning Leydig cell histometry in the rabbit is scarce. A previous attempt to correlate Leydig cell mass with testosterone secretion in this species has indicated that no such relationship exists (6). Therefore, the objective of the present study was to identify possible associations between plasma and tissue testosterone levels and the spermatogenic efficiency as well as volume density and number of Leydig cells.

\section{Material and Methods}

\section{Animals}

Twelve 8-month-old sexually mature New Zealand White rabbits were used. Rabbits were maintained in individual cages under a controlled environment consisting of a 12-h light-dark cycle and ambient temperature of $22^{\circ} \mathrm{C}$ and were provided with feed and water ad libitum for at least 90 days before use for this study. The animals were first tranquilized with ketamine (Ketaset, Aveco, Fort Dodge, IA, USA) intramuscularly and blood was collected by cardiac puncture for hormonal analysis. Upon anesthesia, animals were sacrificed by an intracardiac overdose of injected Nembutal.

\section{Tissue collection}

After sacrifice, the right or the left testis from each animal was removed for histological analysis of the seminiferous tubules and for hormonal assay of testicular testosterone. Body and testicular weights were recorded for each animal. A small portion of the testis was frozen $\left(-18^{\circ} \mathrm{C}\right)$ until used for analysis of its testosterone content. For the histological analyses, tissue fragments approximately $2 \mathrm{~mm}^{3}$ in size were collected from several regions of the testis (except from the mediastinal region), fixed by immersion in 5\% glutaraldehyde, and rinsed in cacodylate buffer solution. Fragments were subsequently dehydrated through a series of increasing ethanol concentrations, infiltrated and embedded in glycol methacrylate (JB-4 Plus, Polysciences Inc., Warrington, PA, USA) as described by Russell and collaborators (7). After embedding, tissue blocks were cut to provide $2-\mu \mathrm{m}$ sections using a ReichertJung Ultracut E microtome. Sections were mounted on glass slides and routinely stained with toluidine blue.

\section{Q uantitative testicular histology}

Round tubular cross-sections of seminiferous tubules were examined by light microscopy and classified into stages of the seminiferous epithelium cycle by the acrosomic system method (5). The number of Sertoli cell nuclei with evident nucleoli as well as the number of germ cell nuclei were recorded in at least 10 round tubular crosssections at stage VII of the seminiferous epithelium cycle per animal. The resulting crude counts, which represented both whole and sectioned nuclei, were corrected to true counts using Abercrombie's correction factor (8). After this first correction, data were further adjusted by a Sertoli correction factor (9) and are reported as the ratio between germ cells and Sertoli cells per tubular crosssection. Abercrombie's and Sertoli cell cor- 
rection factors serve to adjust for possible variations in nuclear diameter and tubular diameter, respectively. In order to investigate possible relationships between seminiferous tubular diameter and testosterone levels, 20 cross-sections of seminiferous tubules were measured in each of the 12 animals using a calibrated ocular micrometer coupled to a 40X objective.

The spermatogenic efficiency was estimated from both ratios among germ cells and ratios between germ cells and Sertoli cells. This method is useful in quantifying the depletion of specific germ cells as well as the efficiency of spermatogenesis. Therefore, the following ratios were determined: primary spermatocytes in pachytene per spermatogonium, round spermatids per spermatogonium and germ cells (spermatogonia, primary spermatocytes at pachytene and round spermatids) per Sertoli cell. Such ratios were then compared with the concentrations of plasma and tissue testosterone to identify possible associations between these parameters.

\section{Number of Leydig cells}

The volume density approach (10) was used to estimate the population of Leydig cells in the testis. For such procedure, we assumed that since the density of the testis is approximately 1.0 (6), the volume of the testis is nearly equal to its weight, and that the combined volume of the albuginea and the mediastinum in rabbits corresponds to $5 \%$ of the total testicular volume (11). Next, the percent volume occupied by the Leydig cell nuclei was estimated using a 441 point reticule coupled to a $40 \mathrm{X}$ objective. A total of 3000 hits were recorded per testis for each rabbit. The volume of the nucleus of a single Leydig cell was estimated according to the formula of a sphere: volume $=4 / 3 \pi r^{3}$, where $r$ corresponds to the radius of the nucleus of the cell. The diameter of the Leydig cell nucleus was determined by coupling a calibrated ocular micrometer to a $40 \mathrm{X}$ objective.
Thirty Leydig cell nuclear diameters were measured per animal. The total number of Leydig cells in the testis was calculated according to the following formula: number of Leydig cells $=$ volume occupied by the Leydig cell nuclei in the testis $\left(\mu \mathrm{m}^{3}\right) /$ volume of a single nucleus of Leydig cell $\left(\mu \mathrm{m}^{3}\right)$.

The results are reported as total number of Leydig cells per testis as well as on a per gram basis.

\section{Processing for hormonal analysis}

Plasma was obtained by centrifugation at $4^{\circ} \mathrm{C}$ and the androgen (testosterone) extracted with ether according to routine procedures. Testicular tissue was homogenized with a Polytron and tissue androgen was extracted with ether according to the procedure of Condon and Pate (12), modified.

\section{Radioimmunoassay}

Testosterone concentrations were determined by radioimmunoassay using a lyophilized aliquot of \#250 anti-testosterone-11BSA serum obtained from Dr. Gordon Niswender (Colorado State University, Fort Collins, CO, USA). Testosterone -1,2,6,7-[ $\left[{ }^{3} \mathrm{H}\right]$ was obtained from Dupont New England Nuclear Research Products, Boston, MA, USA. Free steroid was separated from bound steroid by charcoal adsorption, and bound counts were determined with a Beckman liquid scintillation counter. The radioimmunoassay method was that proposed by Condon and Pate (12). The limit of sensitivity was $0.125 \mathrm{ng} / \mathrm{ml}$. Thin layer chromatography was used to purify the $\left[{ }^{3} \mathrm{H}\right]$-testosterone tracer by the method of Tsang and Callard (13). Concerning testosterone levels, the intra- and interassay coefficients of variation were 6.9 and $12.6 \%$, respectively.

\section{Statistical analysis}

The statistical methods consisted of descriptive analysis (mean \pm standard error of 
the mean) and Pearson correlation analysis and were performed with the SigmaStat for Windows 1994 software (Jandel Scientific Corporation, San Rafael, CA, USA).

\section{Results and Discussion}

The data obtained in the present investigation are summarized in Table 1. Plasma and tissue testosterone levels within individual rabbits correlated highly with each other ( $\mathrm{r}=0.94, \mathrm{P}<0.05)$.

Neither plasma nor testicular testosterone levels were correlated significantly with any of the following parameters: seminiferous tubular diameter, number of Sertoli cells per tubular cross-section, ratios between germ cells and Sertoli cells and ratios among germ cells. However, both plasma and tissue levels of testosterone correlated highly with the

\begin{tabular}{|c|c|c|}
\hline & Mean \pm SEM & Range \\
\hline Body weight (kg) & $4.29 \pm 0.08$ & $3.77-4.67$ \\
\hline Testis weight (g) & $3.60 \pm 0.09$ & $2.80-4.60$ \\
\hline Plasma testosterone $(\mathrm{ng} / \mathrm{g})^{1}$ & $4.97 \pm 0.99$ & $0.51-9.16$ \\
\hline Testicular testosterone $(\mathrm{ng} / \mathrm{g})^{1}$ & $254.66 \pm 56.02$ & $37.18-521.56$ \\
\hline Seminiferous tubular diameter $(\mu \mathrm{m})$ & $299.10 \pm 4.70$ & $281.10-329.5$ \\
\hline Sertoli cells/tubular cross-section & $3.13 \pm 0.03$ & $2.70-3.62$ \\
\hline \multicolumn{3}{|l|}{ Germ cell/Sertoli cell ratio ${ }^{2}$} \\
\hline Spermatogonia & $0.34 \pm 0.03$ & $0.22-0.45$ \\
\hline Primary spermatocytes & $3.73 \pm 0.09$ & $3.21-4.14$ \\
\hline Round spermatids & $11.62 \pm 0.40$ & $9.89-14.06$ \\
\hline \multicolumn{3}{|l|}{ Germ cell/spermatogonium ratio 2} \\
\hline Primary spermatocytes & $11.49 \pm 0.66$ & $7.02-14.59$ \\
\hline Round spermatids & $36.16 \pm 2.66$ & $19.62-52.07$ \\
\hline \multicolumn{3}{|l|}{ Leydig cell parameters } \\
\hline Nuclear volume density $(\%)^{3}$ & $1.40 \pm 0.04$ & $1.10-1.6$ \\
\hline Nuclear diameter $(\mu \mathrm{m})$ & $9.80 \pm 0.07$ & $9.40-10.4$ \\
\hline Nuclear volume $\left(\mu \mathrm{m}^{3}\right)$ & $492.90 \pm 11.1$ & $435.00-589.1$ \\
\hline Leydig cells/testis (x 106) & $103.70 \pm 5.77$ & $71.30-132.0$ \\
\hline Leydig cells/g testis $\left(\times 10^{6}\right)$ & $28.60 \pm 1.30$ & $18.80-34.4$ \\
\hline
\end{tabular}

${ }^{1}$ Numbers for individual rabbits refer to means of duplicate assays of two concentrations from the same sample.

${ }^{2}$ Numbers obtained from a total of approximately 50,000 crude counts (including whole nuclei and nuclear fragments); all values represent true counts.

3 Indicates the percent of total testis volume occupied by the Leydig cell nuclei. percent volume of Leydig cell nuclei $(\mathrm{r}=$ 0.82 and 0.78 , respectively, $\mathrm{P}<0.05$ ) and the number of Leydig cells per gram of testis $(r=$ 0.83 and 0.82 , respectively, $\mathrm{P}<0.05)$. Plasma testosterone level also correlated with the total number of Leydig cells per testis $(\mathrm{r}=$ $0.71, \mathrm{P}<0.05)$. In addition, a high correlation was observed between the percent volume of Leydig cell nuclei and the number of Leydig cells per gram of testis $(r=0.94$, $\mathrm{P}<0.05)$ and, to a lesser extent, between the percent volume of Leydig cell nuclei and the total number of Leydig cells per testis ( $\mathrm{r}=$ $0.60, \mathrm{P}<0.05$ ).

Although several other androgens (such as dihydrotestosterone, dehydroepiandrosterone and androstenedione) are produced in small amounts by the rabbit testis, testosterone appears to be the major androgen in the blood of a variety of species, including the rabbit $(3,4)$. Our results indicate, however, that both plasma and testicular levels of testosterone exhibit a broad range of variation among adult rabbits. In spite of this variation, the values obtained in the present investigation agree with those previously reported by a similar method of analysis (1416). As expected, plasma and testicular tissue levels of testosterone were correlated, since the major source of testosterone is that of testicular origin.

Surprisingly, no correlation was found between plasma and testicular testosterone levels and the parameters indicative of spermatogenic efficiency. Thus, in spite of the essential role of testosterone in the maintenance of the normal spermatogenic process, it appears from our data that elevated levels of this hormone above basal levels do not influence the spermatogenic efficiency of adult rabbits. As such, additional testosterone, under normal conditions, apparently is not capable of improving such efficiency, at least in this species. Therefore, the increase in sperm production efficiency may depend upon other factors, such as the increase of Sertoli cell population that precedes puberty (17). 
The mean value obtained in the present study for the percent volume of Leydig cell nuclei $(1.4 \%$, range $1.1-1.6 \%)$ was lower than the $2.24 \%$ value reported by Ewing et al. (6). On the other hand, values found in rabbits are quite different from the 16.2\% value reported by Kothari et al. (18) in albino rabbits, but, as pointed out by Ewing et al. (6), there is no apparent explanation for this extreme value. Regarding the other Leydig cell parameters analyzed in this paper (mean nuclear diameter and volume, number of cells per gram of testis and total number of cells per testis), no data for rabbits are available in the literature. Our values are, however, within the range ( 6.2 to $28 \times 10^{6}$ cells per gram of testis and 10.0 to $13,200 \times 10^{6}$ cells per testis) reported for most laboratory and domestic species (19).

The significant correlations $(\mathrm{P}<0.05)$ observed between the number of Leydig cells per gram of testis and both plasma and testicular levels of testosterone suggest that in the rabbit the increase in testosterone might occur as a consequence of the increase in the population of androgen-secreting cells. Thus, estimation of this population would be useful as a criterion for monitoring testosterone levels of rabbits under normal conditions.

A correlation was also found between plasma and testicular testosterone levels and percent volume of Leydig cells. This is in contrast with the report by Ewing et al. (6) who did not report any association between these parameters in rabbits or in other species such as rat, guinea pig, dog and hamster. According to these authors the species differences in testosterone secretion might be due to some qualitative differences in Leydig cell structure and/or function. Furthermore, the same investigators speculated that there might be a strong correlation between testosterone secretion and the amount of membranous structures present in either the mito- chondria and/or smooth endoplasmic reticulum of Leydig cells in different species. Indeed, a significant positive linear correlation $(r=0.99)$ between testosterone secretion and the volume density of smooth endoplasmic reticulum was reported later by Zirkin et al. (20) in five mammalian species, including the rabbit. Another factor involved in testosterone synthesis by Leydig cells is the direct relationship between the binding activity of androgen receptors and the number and size of Leydig cells, as was demonstrated by Tripepi et al. (21) in the domestic pig at different biological stages of development.

The discrepancy between the results of the present study and those of Ewing et al. (6) is probably due to differences in the methodology employed for both testosterone assay and volume density determination. For example, in the study of Ewing et al. (6) one testis was used for the estimation of Leydig cell percent volume while the testosterone assay was performed on the contralateral one. In the present investigation, however, the same testis was used for both tissue testosterone assay and histological evaluation. Furthermore, in the study by the above mentioned investigators, the testosterone assay included in vitro perfusion of the testis with ovine luteinizing hormone to stimulate testosterone secretion, while in our investigation the testis was not submitted to any additional hormone treatment before testosterone radioimmunoassay.

As an additional remark, it should be emphasized that the absence of a correlation between testosterone concentration and any of the measures of spermatogenic activity is consistent with the possibility that testosterone concentrations need only meet or exceed some minimal threshold level for spermatogenesis to proceed normally in the rabbit. 


\section{References}

1. Sharpe RM, Donachie $K \&$ Cooper I (1988). Re-evaluation of the intratesticular level of testosterone required for quantitative maintenance of spermatogenesis in the rat. J ournal of Endocrinology, 117: 19-26.

2. Poccia D (1994). Intercellular signaling systems. In: Poccia D (Editor), Molecular Aspects of Spermatogenesis. R.G. Landes Company, Austin, TX, USA.

3. Ewing LL \& Eik-Nes KB (1966). On the formation of testosterone by the perfused rabbit testis. Canadian J ournal of Biochemistry, 44: 1327-1344.

4. Gustafson AW \& Shemesh M (1976). Changes in plasma testosterone levels during the annual reproductive cycle of the hibernating bat, Myotis lucifugus lucifugus with a survey of plasma testosterone levels in adult male vertebrates. Biology of Reproduction, 15: 9-24.

5. Castro ACS (1995). A proposed acrosomal system for identifying stages of the cycle of the seminiferous epithelium and a model for the kinetics of spermatogenesis in the rabbit. Doctoral thesis, University of New Hampshire, Durham, NH, USA.

6. Ewing LL, Zirkin BR, Cohran RC, Kromann N, Peters C \& Ruiz-Bravo N (1979). Testosterone secretion by rat, rabbit, guinea pig, dog, and hamster testes perfused in vitro: correlation with Leydig cell mass. Endocrinology, 105: 1135-1142.

7. Russell LD, Ettlin RA, Sinha-Hikim AP \& Clegg ED (1990). Tissue preparation for evaluation of the testis. In: Russell LD, Ettlin RA, Sinha-Hikim AP \& Clegg ED
(Editors), Histological and Histopathological Evaluation of the Testis. Cache River Press, Clearwater, FL, USA.

8. Abercrombie M (1946). Estimation of nuclear population from microtome sections. Anatomical Record, 94: 239-247.

9. Clermont $Y \&$ \& Morgenthaler H (1955). Quantitative study of spermatogenesis in the hypophysectomized rat. Endocrinology, 57: 369-382.

10. Chalkley HW (1943). Method for quantitative morphologic analysis of tissues. J ournal of the National Cancer Institute, 4: 4753.

11. Amann RP (1970). The male rabbit. IV. Quantitative histology and comparisons between daily sperm production as determined histologically and daily sperm output. Fertility and Sterility, 21: 662-672.

12. Condon WA \& Pate J L (1981). Influence of serum and its lipoprotein fractions on progesterone synthesis and secretion by bovine luteal tissue in vitro. Biology of Reproduction, 25: 950-957.

13. Tsang PCW \& Callard IP (1992). Regulation of ovarian steroidogenesis in vitro in the viviparous shark, Squalus acanthias. J ournal of Experimental Zoology, 261: 97104.

14. Nieschlag E, Teekook W, Usadel KH, Kley HK \& Kruskemper HL (1975). Testicular testosterone concentration and in vitro response to HCG in normal and in testosterone immunized rabbits. Steroid, 25: 379-386.

15. Rowe PH, Shenton JC \& Glover TD (1973). Testosterone levels in peripheral blood plasma of the rabbit under normal and experimental conditions. Acta Endocrinologica, 177 (Suppl): 125 (Abstract).

16. Smith OW \& Hafs HD (1973). Competitive protein binding and radioimmunoassay for testosterone in bulls and rabbits; blood serum testosterone after injection of $\mathrm{LH}$ or prolactin in rabbits. Proceedings of the Society for Experimental Biology and Medicine, 142: 804-810.

17. França LR, Hess RA, Cooke PS \& Russel LD (1995). Neonatal hypothyroidism causes delayed Sertoli cell maturation in rats treated with propylthiouracil: evidence that the Sertoli cell controls testis growth. Anatomical Record, 242: 57-69.

18. Kothari LK, Patri MK \& J ain ML (1978). The total Leydig cell volume of the testis in some common mammals. Andrologia, 10: 218-222.

19. Russell LD (1996). Mammalian Leydig cell structure. In: Payne AH, Hardy MP \& Russell LD (Editors), The Leydig Cell. Cache River Press, Clearwater, FL, USA.

20. Zirkin BR, Ewing LL, Kromann N \& Cochran RC (1980). Testosterone secretion by rat, rabbit, guinea pig, dog and hamster testes perfused in vitro: correlation with Leydig cell ultrastructure. Endocrinology, 107: 1867-1874.

21. Tripepi S, Carelli A, Pierrotta E, Brunelli E, Tavolaro R, Facciolo RM \& Canonaco M (2000). Morphological and functional variations of Leydig cells in testis of the domestic pig during the different biological stages of development. J ournal of Experimental Zoology, 287: 167-175. 